\title{
Notes on Neotropical Proconiini (Hemiptera: Cicadellidae: Cicadellinae). VI: description of the male of Deselvana falleni from the Atlantic Rainforest of southeastern Brazil
}

\author{
Gabriel Mejdalani ${ }^{1,2}$; André Carpi ${ }^{1} \&$ Rachel A. Carvalho ${ }^{1}$ \\ ${ }^{1}$ Departamento de Entomologia, Museu Nacional, Universidade Federal do Rio de Janeiro. Quinta da Boa Vista, São \\ Cristóvão, 20940-040 Rio de Janeiro, Rio de Janeiro,Brasil.E-mail: mejdalan@acd.ufrj.br; gmejdalani@uol.com.br \\ 2 Corresponding author.
}

\begin{abstract}
The male of the leafhopper Deselvana falleni (Stål, 1858) is for the first time described and illustrated based on material from the state of Rio de Janeiro, Brazil. Notes comparing D. falleni to other species of Deselvana Young, 1968 are given. Males and females of $D$. falleni can be recognized by the dark brown to black dorsum with four well-defined yellow maculae on each forewing, two on clavus and two on corium. The sexual dimorphism of color found in other Deselvana species was not observed in $D$. falleni.
\end{abstract}

KEY WORDS. Auchenorrhyncha; male genitalia; Membracoidea; sharpshooter; taxonomy.

This is the sixth paper of a series on the taxonomy of the Proconiini in the Neotropical region. The previous papers of the series included descriptions of four new species and notes on other species in the tribe (Mejdalani \& Emmrich 1998, Сeotto et al. 2000, Mejdalani 2006, Mejdalani et al. 2006, 2008).

Deselvana falleni (Stål, 1858) was so far known only from the female (STÅL 1858, 1862, Melichar 1925, Young 1968). Due to the distinctive color pattern of this rare species, we have been able to identify a male specimen from the Atlantic Rainforest of the state of Rio de Janeiro, southeastern Brazil, which is described and illustrated below. This male was also compared to a photograph of the female holotype of D. falleni (from "Rio de Janeiro") available in the recently published internet site "Sharpshooter Leafhoppers of the World" (Wilson \& TURNer 2008). The specimen belongs to the collection of the Departamento de Entomologia, Museu Nacional, Universidade Federal do Rio de Janeiro, Rio de Janeiro (MNRJ). The morphological terminology adopted herein follows mainly Young (1968), except that of the facial areas of the head (Hamilton 1981, Mejdalani 1998). The photographs were prepared with the software Automontage (Synoptics Inc., Frederick, Maryland, USA).

\section{TAXONOMY}

\section{Deselvana Young, 1968}

Deselvana Young, 1968: 151. Type-species: Proconia excavata Le Peletier \& Serville, 1825: 611, by original designation.

Remarks. Young (1968) included 11 species in Deselvana. According to him, this Neotropical genus apparently ranges from Panama to southern Brazil and Peru. However, he mentioned that specimens from Venezuela were unknown to him. He con- sidered Deselvana closely related to Raphirhinus de LaPorte, 1832, Omagua Melichar, 1925, and Abana Distant, 1908, with which it shares the distinctive dorsal concavity of the male pygofer. In the cladistic analysis of the Abana group of genera (Сеотто \& Mejdalani 2005), Deselvana appeared in a monophyletic group that also included Raphirhinus, Omagua, and Abana, as well as Teletusa Distant, 1908. However, the results of Ceotto \& Mejdalani (2005) also suggested that Deselvana is a polyphyletic taxon. Thus, the current phylogenetic status of the genus is unclear. In its present sense, Deselvana can be distinguished from the aforementioned genera, as well as from other Proconiini genera, by the following combination of features (Young 1968): (1) head strongly produced anteriorly, without a threadlike apical process (Fig. 3); (2) clypeus not produced, its contour continuing the profile of frons (Fig. 4); (3) posterior meron exposed when the forewings are in rest position (Fig. 4); (4) male pygofer with a distinct dorsal concavity (Fig. 6); (5) aedeagus with the gonopore simple, not greatly enlarged (Fig. 9).

\section{Deselvana falleni (Stål, 1858)}

Figs 1-10

Tettigonia falleni Stål, 1858: 249. Holotype in the Naturhistoriska Riksmuseet (Stockholm) (Young 1963), photographed by Wilson \& Turner (2008). The species was catalogued by Metcalf (1965), Young (1968), and McKamey (2007).

Description. Male. Length, $19.8 \mathrm{~mm}$. Body long and slender.

Head. Head (Figs 3 and 4) strongly produced; median length of crown approximately equal to interocular width and approximately six-tenths transocular width; apex slightly carinate at tran- 
sition from crown to face. Crown (Fig. 3) with median, apically expanded longitudinal fovea; disc with sparse pubescence; ocelli located slightly behind imaginary line between anterior eye angles, each ocellus approximately equidistant to anterior eye angle and median line of crown; without longitudinal carina adjacent to each ocellus; posterior margin without median Mshaped elevation. Antennal ledges (Fig. 4), in lateral view, without longitudinal concavity. Face (Fig. 4) with hair-like setae longer on lower portion than on upper portion; frons flattened medially, depressed on upper portion, muscle impressions distinct; clypeus not produced, its contour continuing profile of frons.

Thorax. Pronotum (Fig. 3) width slightly greater than transocular width of head; lateral pronotal margins slightly convergent anteriorly; disc with punctures and rugose on posterior two-thirds, punctures with small associated setae; posterior margin concave; dorsopleural carinae (Fig. 4) complete, arched ventrally. Mesonotum (Fig. 3) with scutellum transversely striate. Forewings (Fig. 5) without distinct membrane; veins elevated and distinct; claval veins approximately parallel; basal half of wings with punctures, mostly along veins, bearing small setae; with three closed anteapical cells, base of inner distinctly more basad than others; with supernumerary anteapical veins to costal margin; number of apical cells affected by the presence of irregular supernumerary veins. Hindwings not extending as far posteriorly as forewings; vein $\mathrm{R}_{2+3}$ incomplete. Forelegs with tibia broadly expanded. Hindlegs with femoral setal formula 2:0:0; first tarsomere shorter than combined length of second and third, with two parallel rows of setae on plantar surface.

Color. Dorsum (Fig. 1) dark brown to black with four distinct yellow maculae on each forewing: two on clavus (one near base and another near scutellar apex, the latter transverse, extending from claval sulcus to commissural margin) and two on corium (one at basal half, extending from costal margin to brachial cell, and another on apical half, extending from costal margin to inner anteapical cell). Face mostly dark brown to black; rostrum yellowish-brown. Thorax mostly dark brown to black; anterior and middle legs yellow to yellowish-brown with black coxae; posterior legs with black coxae, femora brown with yellow ends, tibiae brown, tarsomeres whitish-yellow, contrasting strongly with tibiae (Fig. 2).

Genitalia. Pygofer (Fig. 6), in lateral view, strongly triangularly produced posteriorly; with concavity on posterior half of dorsal margin; apex narrowly rounded; with scattered setae located mostly on apical half and extending anteriorly over inferior portion; without processes. Valve (Fig. 7), in ventral view, subrectangular, transverse. Subgenital plates (Fig. 7), in ventral view, separated throughout their length, extending as far posteriorly as pygofer apex, each triangular, narrowing gradually toward apex; in lateral view, with small dentiform projection on basal third located posteriorly to style apex, with scattered setae ventrally and dorsally, those on apical half much longer. Styles (Fig. 8), in dorsal view, extending as far posteri-

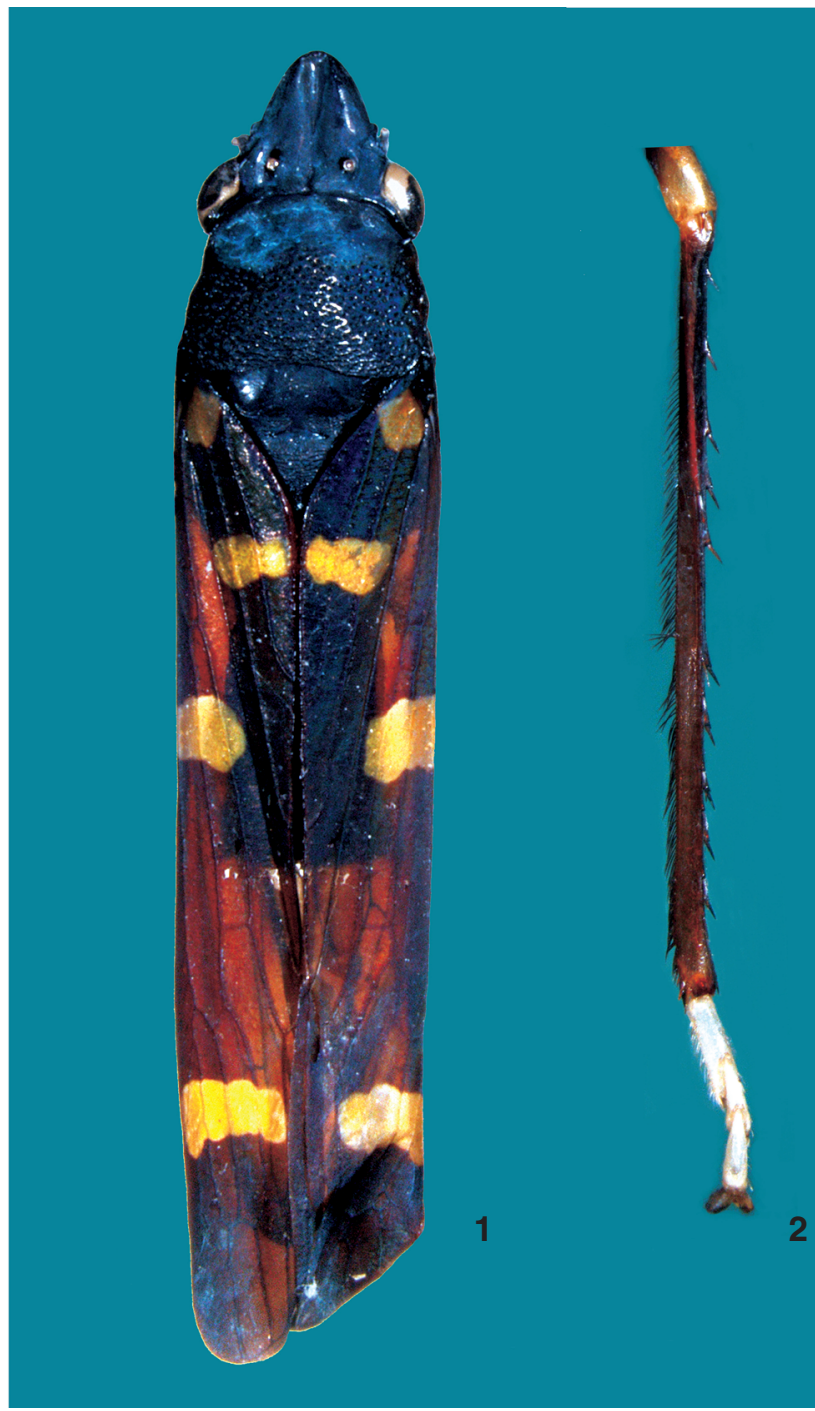

Figures 1-2. Deselvana falleni, male: (1) dorsal habitus; (2) hind tibia and tarsus, showing the contrasting coloration between them.

orly as apex of connective; with preapical lobe; preapical portion with few setae; apical portion foot-shaped, directed outward; apex truncate. Connective (Fig. 8), in dorsal view, Yshaped; arms very short; stem broad, longer than arms, with slight median keel. Aedeagus (Figs 9 and 10) symmetrical; base, in lateral view, with pair of small quadrangular projections directed posteriorly and with serrate apex (Fig. 9); shaft, in lateral view, strongly curved dorsally and then posteriorly, sinuous, basal half with pair of small triangular processes (Fig. 9), their apexes close to those of quadrangular projections (in caudal view, these processes are more conspicuous and projected laterally, Fig. 10); apex truncate in lateral view (Fig. 9), with pair of projections in caudal view (Fig. 10). Paraphyses (Figs 9 

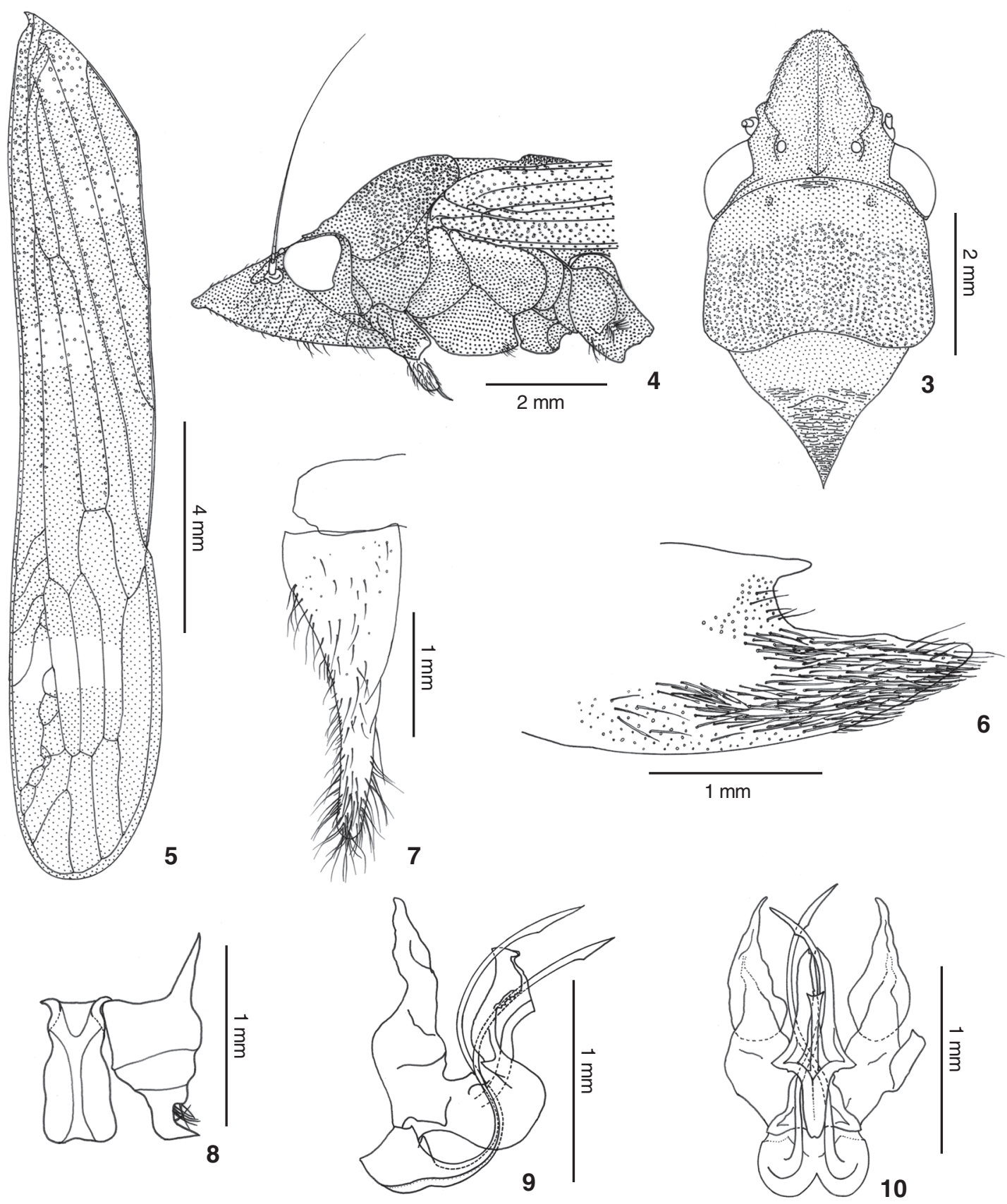

Figures 3-10. Deselvana falleni, male: (3) crown, pronotum, and mesonotum, dorsal view; (4) anterior portion of body, lateral view; (5) forewing; (6) pygofer, lateral view (basal margin omitted); (7) valve and subgenital plate, ventral view (lateral margin of valve damaged); (8) style and connective, dorsal view; (9) aedeagus and paraphyses, lateral view; (10) aedeagus and paraphyses, caudal view.

and 10) paired, associated with aedeagus at their bases; rami very long and sinuous, crossing each other, slightly expanded preapically, extending farther posteriorly than aedeagal apex.

Material examined. One male: BraziL, Rio de Janeiro:
Itatiaia (Parque Nacional do Itatiaia, 1250 m), 30.X.2008, M.L. \& M.A. Monné (MNRJ).

Remarks. The male specimen examined was identified as D. falleni using the original description of the species (STÅL 1858) 
and the photograph of the female holotype provided by WILSON \& TuRner (2008). The dark brown to black dorsum (Fig. 1) with four distinct yellow maculae on each forewing, two on clavus and two on corium, is apparently unique within the genus, allowing the identification of the species. Another distinctive feature is the whitish-yellow color of the hind tarsomeres, contrasting strongly with the brown tibiae. This peculiar feature (Fig. 2) was mentioned by Stål in the original description ("tarsi flavo-albidi"). The remarkable sexual dimorphism of color mentioned by Ceotto \& Mejdalani (2005) for other Deselvana species - D. excavata (Le Peletier \& Serville, 1825), D. ornata (Blanchard, 1840), and Deselvana sp. - was not observed in $D$. falleni.

Unfortunately, the aedeagus and other parts of the male genitalia were illustrated only for three other species of Deselvana (Young 1968), D. excavata, D. dorsivitta (Walker, 1851), and D. longipennis (Melichar, 1925). Considering that the current phylogenetic status of Deselvana is unclear (see notes above), it is important to mention that the male genitalia of $D$. falleni (Figs 6-10), as well as the external characters (Figs 1-5), are quite similar to those of the type-species, D. excavata. Thus, D. falleni is likely to remain in Deselvana after a comprehensive revision of the genus is carried out. The aedeagus (Figs 9 and 10) of D. falleni, although similar to that of the three above-cited species, shows morphological differences that are taxonomically useful, such as a pair of quadrangular projections on the basal area, a pair of triangular processes on the basal half and the sinuous shaft with the apical portion curved posteriorly.

The male specimen of $D$. falleni was collected in the submontane Atlantic Rainforest of the state of Rio de Janeiro (Itatiaia National Park, $1250 \mathrm{~m}$ a.s.l.). Other species of Deselvana recorded from the state of Rio de Janeiro are: D. excavata, $D$. ornata, and D. pervirgata (Amyot \& Serville, 1843). Unfortunately, nothing is known about the biology of the species of Deselvana.

\section{ACKNOWLEDGMENTS}

We are grateful to M.A. Monné and M.L. Monné (MNRJ), who collected the specimen herein described. The manuscript benefited from the useful comments of D.M. Takiya (Departamento de Zoologia, UFRJ), M.D. Webb (The Natural History Museum, London), and two anonymous reviewers. This research was supported in part by the Fundação de Amparo à Pesquisa do Estado do Rio de Janeiro (FAPERJ; grant E-26/ 171.281/2006). R.A. Carvalho has a fellowship from the Conselho Nacional de Desenvolvimento Científico e Tecnológico (CNPq) in connection with her D.Sc. studies in the Museu Nacional (UFRJ). The undergraduate student A. Carpi has a FAPERJ fellowship.

\section{LITERATURE CITED}

Ceotto, P.C.; G. Mejdalani \& M. Felix. 2000. Notes on Neotropical Proconiini (Hemiptera, Cicadellidae, Cicadellinae), II: description of the female of Anacrocampsa wagneri Young, 1968. Boletim do Museu Nacional (Zoologia) 435: 1-8.

Ceotto, P.C. \& G. Mejdalani. 2005. Phylogenetic analysis of the Abana group of genera (Hemiptera: Cicadellidae: Cicadellinae: Proconiini). Systematic Entomology 30: 480-496.

Hamilton, K.G.A. 1981. Morphology and evolution of the rhynchotan head (Insecta: Hemiptera, Homoptera). Canadian Entomologist 113: 953-974.

Le Peletier de Saint-Fargeau, Amedee, L.M. \& Audinet-Serville, J.G. 1825. Encyclopédie Méthodique. Histoire Naturelle. Entomologie, ou Histoire Naturelle des Crustacés, des Arachnides et des Insectes. Tome Dixième. Paris, Chez Agasse, p. 600-613.

McKamey, S.H. 2007. Taxonomic catalogue of the leafhoppers (Membracoidea). Part 1. Cicadellinae. Memoirs of the American Entomological Institute 78: 1-394.

Mejdalani, G. 1998. Morfologia externa dos Cicadellinae (Homoptera, Cicadellidae): comparação entre Versigonalia ruficauda (Walker) (Cicadellini) e Tretogonia cribrata Melichar (Proconiini), com notas sobre outras espécies e análise da terminologia. Revista Brasileira de Zoologia 15: 451-544.

Mejdalani, G. 2006. Notes on Neotropical Proconiini (Hemiptera: Cicadellidae: Cicadellinae), III: redescription of the Amazonian sharpshooter Ichthyobelus youngi Kramer. Deutsche Entomologische Zeitschrift 53: 108-113.

Mejdalani, G. \& R. Emmrich. 1998. Notes on Neotropical Proconiini: new species of Acrobelus Stål and Dichrophleps Stål and the male of Proconosama haenschi (Melichar) (Insecta: Auchenorrhyncha: Cicadellidae: Cicadellinae). Entomologische Abhandlungen des Staatlichen Museums für Tierkunde Dresden 58: 131-140.

Mejdalani, G.; D.M. Takiya \& R.A. Carvalho. 2006. Notes on Neotropical Proconiini (Hemiptera: Cicadellidae: Cicadellinae), IV: lectotype designations of Aulacizes Amyot \& AudinetServille species described by Germar and revalidation of $A$. erythrocephala (Germar, 1821). Arthropod Systematics \& Phylogeny 64: 105-111.

Mejdalani, G.; L.A.A. Costa \& R.A. Carvalho. 2008. Two new species of Zyzzogeton Breddin and the female of $Z$. haenschi Breddin (Hemiptera: Cicadellidae: Cicadellinae: Proconiini). Journal of Natural History 42: 1639-1648.

Melichar, L. 1925. Monographie der Cicadellinen. II. Annales Historico-Naturales Musei Nationalis Hungarici 22: 329-410.

Metcalf, Z.P. 1965. General catalogue of the Homoptera. Fascicle VI, Cicadelloidea. Part 1, Tettigellidae. Washington, D.C., Agricultural Research Service, United States Department of Agriculture, 730p.

STÅL, C. 1858. Några nya genera och arter bland Hemiptera. Kongliga Svenska Vetenskaps-Akademiens Öfversigt af Förhandlingar 15: 248-250.

STÅL, C. 1862. Bidrag till Rio Janeiro - Traktens Hemipter - Fauna. Kongliga Svenska Vetenskaps-Akademiens Handlingar 3: $1-70$. 
WiLson, M.R. \& J. TuRnER. 2008. Sharpshooter leafhoppers of the world (Hemiptera: Cicadellidae subfamily Cicadellinae). Available online at http://naturalhistory.museumwales.ac.uk/ sharpshooters/home.php [Accessed: 3/I/2009].

Young, D.A. 1963. Types of Cicadellinae (Homoptera, Cica- dellidae) in the Naturhistoriska Riksmuseet in Stockholm. Entomologisk Tidskrift 84: 224-227.

Young, D.A. 1968. Taxonomic study of the Cicadellinae (Homoptera: Cicadellidae), Part 1, Proconiini. Bulletin of the United States National Museum 261: 1-287.

Submitted: 08.V.2009; Accepted: 23.XI.2009.

Editorial responsibility: José Albertino Rafael 